\title{
Surviving the Mongols. Nizārī Quhistānī and the Continuity of Ismaili Tradition in Persia. London/ New York, IB Tauris Publishers/The Institute of Ismaili Studies, 2002, $190 \mathrm{p}$.
}

\section{Ève Feuillebois-Piérunek}

\section{OpenEdition}

Journals

Édition électronique

URL : http://journals.openedition.org/abstractairanica/20661

DOI : 10.4000/abstractairanica.20661

ISSN : 1961-960X

Éditeur :

CNRS (UMR 7528 Mondes iraniens et indiens), Éditions de l'IFRI

Édition imprimée

Date de publication : 15 mai 2007

ISSN : 0240-8910

\section{Référence électronique}

Ėve Feuillebois-Piérunek, « Surviving the Mongols. Nizārī Quhistānī and the Continuity of Ismaili Tradition in Persia. London/New York, IB Tauris Publishers/The Institute of Ismaili Studies, 2002, 190 p. », Abstracta Iranica [En ligne], Volume 28 | 2007, document 332, mis en ligne le 18 septembre 2007, consulté le 25 septembre 2020. URL : http://journals.openedition.org/abstractairanica/20661 ; DOI : https://doi.org/10.4000/abstractairanica.20661

Ce document a été généré automatiquement le 25 septembre 2020.

Tous droits réservés 


\section{Surviving the Mongols. Nizārī Quhistāni and the Continuity of} Ismaili Tradition in Persia. London/ New York, IB Tauris Publishers/The Institute of Ismaili Studies, 2002, 190 p.

Ève Feuillebois-Piérunek

1 Deux grandes parties composent ce livre. La première, qui occupe un tiers du texte et constitue une sorte d'introduction, survole le développement de la da'wa ismaélienne des débuts à la conquête mongole, tout en s'efforçant de montrer comment celle-ci a permis de maintenir l'identité religieuse et la cohésion de la communauté. Le reste de l'ouvrage est consacré à l'étude du Safar-nāma de Nizārī, et à la manière dont il révèle la continuité de la da wa sous le pouvoir mongol. Ce Récit de voyage est quasiment la seule source ismaélienne pour cette époque et éclaire les relations entre ismaélisme et soufisme. Malheureusement, l'A. n'en dit quasiment rien, si ce n'est quelques généralités d'une grande banalité, au point que l'on se demande si elle l'a réellement lu. Cet ouvrage est très décevant : il manque cruellement de profondeur, et n'apporte rien de nouveau à notre connaissance de l'ismaélisme ou de l'œuvre de Nizārī. 
INDEX

Thèmes : 11.1.1. Littérature persane classique

\section{AUTEURS}

ÈVE FEUILLEBOIS-PIÉRUNEK

Sorbonne Nouvelle - Paris III 